УДК 338.28:330.5

Руденко М.В., д.е.н., доцент

Rudenko M., Doctor of Economic Sciences, Associate Professor https://orcid.org/0000-0002-1966-7695

\title{
ЦИФРОВІЗАЦІЯ: КАТЕГОРІАЛЬНІ ОСОБЛИВОСТІ ТА СПЕЦИФІКА ТРАКТУВАННЯ
}

\author{
Університет банківської справи, Черкаський інститут
}

\begin{abstract}
У статті проведено аналіз категоріальних особливостей та специфіки трактування поняття «цифровізація». Виявлено відсутність єдиного однозначного тлумачення наведеної категорії, більшість науковців та практиків пов'язують вищенаведене поняття з теорію інформаційної економіки. Деталізовано розглянуто понятійне поле «цифровізації» в розрізі англомовної наукової літератури та вітчизняних джерел, оскільки досліджуване поняття насичене різними тлумаченнями та інтерпретаціями, в тому числі пов'язаними із перекладом трактування з англійської на українську мову.

Виявлено, що у вітчизняній науці дослідження проблем цифровізації економіки та трактування поняття «цифровізація» не має довгої передісторії, як то на заході. Проведений аналіз дозволяє стверджувати, що теоретичне обгрунтування, тлумачення та використання поняття «цифровізація» в межах вітчизняної науки та суспільства спирається здебільшого на етимологію запозичених закордонних, переважно англомовних, термінів.
\end{abstract}

Визначено, що здебільшого цифровізація розглядається закордонними та вітчизняними авторами як окремий сучасний науковий напрям, а основна частина досліджень сконцентрована на впливі цифровізації на сталий розвиток економічних систем в розрізі окремих країн, регіонів, галузей, підприємств.

Проведено групування поняття «цифровізація» та визначень науковців згідно технологічного, економічного, соціального, філософського та нормативного підходів з окресленням сутності трактування кожної групи, що дозволило систематизувати вектори визначення категорії «цифровізація» в умовах сучасного динамічного розвитку економіки та суспільства.

Ключові слова: поняття «циифровізачія», особливості трактування, категорія, цифрова економіка, суспільні відносини, підхід.

\section{THE DIGITALIZATION: CATEGORY FEATURES AND SPECIFICS OF INTERPRETATION}

\author{
Banking University, Cherkasy Institute
}

The categorical features and specifics of the interpretation of the concept of «digitalization» has been analyzed in the article. The lack of a single unambiguous interpretation of this category has been revealed, and most scholars and practitioners associate the above concept with the theory of information economy. The conceptual field of «digitalization» in the context of English-language scientific literature and domestic sources is considered in detail, as the studied concept is full of different interpretations and interpretations, including those related to the translation of interpretation from English into Ukrainian.

It has been revealed that in domestic science the study of the problems of digitalization of the economy and the interpretation of the concept of «digitalization» does not have a long history, as in the West. The analysis allows us to state that the theoretical substantiation, interpretation and use of the concept of «digitization» within the domestic science and society is based mainly on the etymology of borrowed foreign, mostly English, terms.

It has been determined that digitalization is mostly considered by foreign and domestic authors as a separate modern scientific field, and the main part of research is focused on the impact of digitalization on sustainable development of economic systems in terms of individual countries, regions, industries and enterprises.

The grouping of the concept of «digitalization» and definitions of scientists according to technological, economic, social, philosophical and normative approaches with outlining the essence of interpretation of each group, which allowed to systematize the vectors of definition of «digitalization» in modern dynamic economic and social development. 
Key words: concept of «digitalization», features of interpretation, category, digital economy, public relations, approach.

Постановка проблеми у загальному вигляді i iï зв'язок 3 важливими науковими та практичними завданнями. Еволюційні зміни у трактуванні ролі інформації та інформаційних технологій в розвитку сучасної економіки та суспільства дозволяють краще зрозуміти підгрунтя сучасних цифровізаційних процесів, які відбуваються не лише в економіці, але і в соціумі [1]. Цифрові трансформації в економіці та суспільстві характеризується великим обсягом накопичених знань навіть у досить вузьких тематичних областях. Знання здатні впливати на всі аспекти діяльності як окремого суб'єкта господарювання, так і економічної системи загалом [2, с. 40]. Розвинені країни, завершивши індустріалізацію, успішно впроваджують цифрові трансформації, прискореними темпами розвивають інноваційні технології, в яких домінує штучний інтелект, автоматизація та цифрові платформи. Розвиток вітчизняного суспільства, створення нових та модернізація існуючих технологій зумовлюють необхідність змін у «звичній» діяльності суб'єктів господарювання, що викликає необхідність чіткого усвідомлення сучасних процесів цифровізації, які розпочинаються 3 розуміння категоріальних особливостей зазначеного поняття та специфіки його застосування.

Аналіз останніх досліджень, у яких започатковано вирішення проблеми. Загальні питання та різні аспекти цифровізації економіки та суспільних відносин останніми роками є доволі популярною темою досліджень не лише зарубіжних вчених, але і вітчизняних науковців та особливо практиків. Серед праць зарубіжних науковців, в розрізі досліджуваних питань, виділимо роботи Дж. С. Бреннена та Д. Крейса [3], Н. Негропонте [4], Д. Тапскота [5]. У вітчизняному науковому полі питання особливостей тлумачення категорії «цифровізація» знайшли відображення в роботах О. С. Вишневського та В. І. Ляшенко [6], О. В. Даннікова та К. О. Січкаренко [7], С. В. Коляденко [8], Н. М. Краус [9], Н. М. Пантелєєвої [10] та інших. Проте динамізм змін викликаних діджиталізацією економічних та суспільних процесів впливають на трактування самої категорії «цифровізація», що потребує додаткових уточнень та поглибленого дослідження суті поняття в межах окремих підходів до визначення.

Мета статті. Проаналізувати категоріальні особливості та специфіку трактування поняття «цифровізація» 3 метою виділення різних підходів до сутності досліджуваної категорії.

Виклад основного матеріалу дослідження 3 повним обгрунтуванням отриманих наукових результатів. Поглиблений аналіз вітчизняної та зарубіжної наукової літератури щодо категоріальних особливостей трактування поняття «цифровізація» дозволяє стверджувати, що на сьогодні не існує єдиного однозначного тлумачення наведеної категорії, проте більшість науковців та практиків пов'язують вищенаведене поняття 3 теорію інформаційної економіки, основи якої закладені Д. Беллом [11], М. Поратом [12], Е. Тоффлером [13] та ін.

Окремі науковці рекомендують використовувати термін «цифровізація» як омонім, оскільки наведена категорія досить багатогранна та має значну кількість трактувань. Загальною метою цифровізаційних процесів в економіці $є$ перебудова виробництва у більш гнучке та пристосоване до реалій сьогодення, що підвищує конкурентоспроможність держави у «цифровому світі». Цифровізація $є$ засобом одержання очікуваного результату, який відповідає вимогам та потребам суспільства i влаштовує виробників та власників бізнесу щодо можливостей отримання стабільних прибутків. 
В науковому розумінні термін «цифровізація» використовується для опису трансформацій, які набагато ширші, ніж просто заміна аналогового або фізичного ресурсу на цифровий або інформаційний. Наприклад, звичайні книги не просто перетворюються на електронні книги, а надають читачеві цілий набір інтерактивних та мультимедійних можливостей. Відповідно, у бізнесі виробничі та управлінські процеси можуть стати он-лайн діалогами між співробітниками і керівниками, які раніше мали досить обмежене спілкування через фізичну віддаленість, застарілі технології, комунікаційні проблеми тощо.

На сьогоднішній день у світі не існує єдиного розуміння такого явища, як «цифрова» економіка та «цифровізація», проте існує безліч трактувань. Одним із перших авторів терміну «цифрова економіка» прийнято вважати директора медіа-лабораторії Массачусетського технологічного інституту Ніколаса Негропонте, який в середині 90-х років XX століття в своїй книзі «Being Digital» («бути цифровим») [4] описує процеси поступової цифровізації суспільства. Автор переконаний, що в майбутньому все що можливо обов'язково буде оцифровано. В своїй роботі автор заклав підгрунтя для сучасного використання терміну «цифровізація».

В подальшому вважаємо за необхідне деталізовано розглянути понятійне поле цифровізації в розрізі англомовної наукової літератури та вітчизняних джерел, оскільки досліджуване поняття насичене різними тлумаченнями та інтерпретаціями, в тому числі пов'язаними із перекладом трактування з англійської на українську мову.

Канадський науковець Д. Тапскотт [5] розглядає цифровізацію як зміну парадигми, яка має місце в суспільстві, 3 широким використанням інформаційнокомунікаційних технологій, які постійно розвиваються та вдосконалюються. Цілком погоджується 3 наведеним твердженням та вважаємо, що цифровізація дійсно є зміною загальної парадигми наших думок, дій, уявлень, механізмів спілкування із зовнішнім світом та один з одним. Проте вважаємо за доцільне підкреслити, що технологія виступає скоріше інструментом цифровізації, ніж ії метою.

Професор колумбійського університету Р. Кац в широкому сенсі під цифровізацію розуміє соціально-економічну трансформацію, яка ініційована масовим впровадженням і використанням цифрових технологій, тобто технологій створення, обробки, обміну і передачі інформації [14]. Визначення науковця має здебільшого технологічну спрямованість, дискусійними залишаються питання, за якими критеріями технології мають відноситися до цифрових, а які все ще залишаються в розряді аналогових. Схожої думки дотримується практик М. Гупта, який вважає, що цифровізація - це удосконалення процесів за рахунок використання цифрових технологій та оцифрованих даних [15].

Група науковців із дослідницького Брукінгського інституту (м. Вашингтон, США) на чолі з М. Муро пов'язує визначення поняття «цифровізація» із бізнесопераціями, ніж з соціальними взаємодіями або бізнес-моделями, хоча очевидно, що всі ці поняття взаємопов'язані. Дослідження проведені в інституті присвячені впливу цифровізації на суспільство та робочу силу. В підсумковому звіті інституту за результатами дослідження наголошується, що цифровізація перетворює світ праці, придбання навичок роботи з цифровими технологіями стало необхідною умовою для індивідуального, промислового, регіонального та національного успіху [16].

Дж. Скотт Бреннен та Д. Крейс говорять про цифровізацію, як про спосіб реструктуризації багатьох областей соціального життя навколо цифрової комунікації і медіа-інфраструктур. Автори засновують своє визначення цифровізації на соціальному житті - іншими словами, на тому, як люди взаємодіють. У міру переходу взаємодії від аналогових технологій (звичайна пошта, телефонні дзвінки) до цифрових (електронна пошта, чат, соціальні мережі), домени як для роботи, так і для відпочинку стають 
цифровими [3]. Зауважимо, що вищенаведене визначення цифровізації базується лише на одній із складових цифровізації - соціальній, проте інші складові залишилися поза увагою поважних науковців.

Дослідники Дж. Грей та Б. Румпе під цифровізацією розуміють використання цифрових технологій для зміни бізнес-моделі і надання нових можливостей отримання прибутку та створення цінності; це процес переходу до цифрового бізнесу [17, с. 1319]. Наведене визначення тісно корелює 3 ідеями, які притаманні практикам із бізнессередовища.

Дослідницька та консалтингова компанія, що спеціалізується на ринках інформаційних технологій Gartner (із штаб-квартирою Коннектикут, США) визначає цифровізацію як «використання цифрових технологій для зміни бізнес-моделі та надання нових можливостей для отримання доходів і створення вартості, це процес переходу до цифрового бізнесу» [18], що дещо відрізняється від трактування цифровізації в академічних та наукових колах, оскільки практики фокусуються саме на зміні бізнесмоделей та розрахунках економічного ефекту від цифровізації, а не на соціальних взаємодіях чи трансформаціях.

У сучасній енциклопедії інформатики та технологій цифровізація трактується як «інтеграція цифрових технологій у повсякденне життя суспільства шляхом оцифровки всього, що можна оцифрувати. Цифровізація означає комп'ютеризацію систем і робочих місць для більшої легкості та доступності» [19], схожої позиції щодо визначення наведеного поняття дотримується професор М. Ел-Шими з університету Айн Шамс (Каїр, Сгипет). Проте ми вважаємо, що вищенаведене визначення має лише технологічну складову без урахування багатогранності інших аспектів цифровізації.

Професор Б. ван Арк досліджуючи сучасні цифровізаційні процеси звертає увагу наукової спільноти на наступний важливий аспект: «за умов цифровізації оцифровка даних та інформації відбувається приголомшливими темпами, проте зростання загальної продуктивності економічних систем має досить скромні результати» [20, с. 3]. Вважаємо, що доволі слушна розстановка акцентів, проте переважна більшість науковців підкреслює довгостроковий ефект від цифровізаційних процесів, саме тому в короткостроковому періоді досить складно простежити стрімке зростання продуктивності як окремих економічних суб'єктів, так і загальних економічних систем.

К. Елдінг та Р. Морріс розглядають цифровізацію через призму технологій, які впливають на основні економічні агрегати, зокрема через конкуренцію, продуктивність на ефекти зайнятості, а також через взаємодію з установами та управлінням [21].

Один із найбагатших людей світ, відомий підприємець Б. Гейтс вбачає у цифровізації можливість компаніям сприймати навколишнє середовище і реагувати на нього, бачити проблеми конкурентів та потреби споживачів і своєчасно реагувати на них [22].

У вітчизняній науці дослідження проблем цифровізації економіки та трактування поняття «цифровізація »не має довгої передісторії, як то на заході, проте привертає досить значну увагу з боку науковців і практиків. У багатьох державах західного світу проблематику формування цифрової економіки та суспільства винесено на державний рівень, що підтверджується прийнятими стратегіями (програмами) розвитку цифрової економіки: Данія - 2000 рік, Сінгапур - 2005 рік, Свропейський Союз, Великобританія, Австралія, Гонконг, Нова Зеландія - 2009 рік, Канада - 2010 рік, Малайзія - 2012 рік, Південна Корея - 2013 рік, Індія, Казахстан - 2015 рік, Росія - 2017 рік, наша держава лише у 2018 році прийняла Концепцію розвитку цифрової економіки та суспільства України на 2018-2020 роки.

Поглиблений аналіз трактування поняття цифровізація у царині вітчизняної науки розпочнемо із схваленої урядової концепції, в якій цифровізація розглядається як 
насичення фізичного світу електронно-цифровими пристроями, засобами, системами та налагодження електронно-комунікаційного обміну між ними, що фактично уможливлює інтегральну взаємодію віртуального та фізичного, тобто створює кіберфізичний простір [23]. Трактування цифровізації в урядовій концепції, на наш погляд, має лише технічну спрямованість (насичення пристроями) та не враховує значної кількості економічних, соціальних, технологічних та інформаційно-комунікаційних аспектів, тому використання наведеного в концепції визначення вважаємо досить обмеженим.

В. І. Ляшенко та О. С. Вишневський розглядають процес цифровізації з позиції поділу економіки на три сектори (первинний - сільське господарство і видобуток корисних копалин, вторинний - промислове виробництво, третинний - послуги), тому принциповою відмінністю $є$ не стільки збільшення частки третинного сектора або появи та розширення нового (цифрової економіки), а радикальне перетворення всіх трьох вже існуючих секторів [6, с. 8].

Позиція наведених науковців тісно корелює з ідеями закладеними К. Кларком та Ж. Фурастьє [24] у теорії постіндустріального суспільства, в якій поділ суспільного виробництва також ділився на три сектори за схожим принципом, науковці наголошували, що в майбутньому стрімко зростатиме частка третинного сектора економіки (сфера послуг) порівняно із сільським господарством та промисловістю. Погоджуємося із твердженням поважних науковців, оскільки за останніми статистичними даними більшості розвинених країн світу саме третинний сектор економіки набуває приголомшливого розвитку (його доля у ВВП більшості країн стрімко зростає), проте переконані, що цифровізаційні процеси прямо пропорційно впливають на перетворення у всіх трьох секторах економіки.

О. В. Данніков та К. О. Січкаренко з інституту економіки та прогнозування НАН України проаналізували сучасний стан цифровізації економіки України, в авторському дослідженні науковці трактують цифровізацію, як нову парадигму розвитку країни, економіки та суспільства у цілому. Цифровізація, на думку науковців, викликає сучасні соціально-економічні трансформації, пов'язані з інформатизацією суспільства [7, с. 75]. Погоджуємося із ідеями авторів, що концептуальне тлумачення економічної категорії «цифровізація» у вітчизняній та світовій науці й досі залишається нечітким.

С. В. Коляденко наголошує, що використання в сучасній економіці новітніх технологій, які охоплюють процеси цифровізації, дасть змогу більш ефективно використовувати знання класичної економічної теорії для вирішення нагальних економічних проблем в розрізі окремих держав, регіонів, галузей і т. д., а також кризових явищ, інфляції, проблем циклічності економіки. Дослідження проведені з використанням цифровізації мають можливість прискорено адоптуватися до економічних реалій сьогодення та виявити шляхи подолання кризового стану суб'єктів господарювання в умовах спадної хвилі глобального економічного розвитку [8, с. 109]. Автор справедливо наголошує на необхідності врахування у наукових економічних дослідженнях сучасних цифровізаційних процесів, оскільки нехтування наведеними тенденціями може призводити до помилкових або неточних умовиводів.

На думку президента Національної академії державного управління при Президентові України В. С. Куйбіди, цифровізацію (digitalization) у широкому розумінні слід трактувати як процес впровадження цифрових технологій для вдосконалення життєдіяльності людини, суспільства і держави [25, с. 7]. Науковець підіймає проблему коректності використання терміну «цифровізація» та схожих категорій, що призводить до певної дихотомії у вітчизняній науці та практичній діяльності суб'єктів господарювання.

Цифровізацію, за переконанням Н. М. Краус, варто розглядати як інструмент досягнення мети сталого розвитку, а не як самоціль. В межах вітчизняної економіки, 
підкреслює науковець, при системному державному стимулюванні інформаційнокомунікаційні технології здатні прискорити розвиток «нового» суспільства, в основі якого закладені базові принципи (економічні, технологічні, соціальні і т.д.) покращення життя громадян нашої держави [9]. Погоджуємося із думкою авторів, що цифровізація не $є$ самоціллю, іiі метою $є$ позитивні зрушення в усіх аспектах соціально-економічного життя соціуму.

Найбільш очевидним трактуванням поняття «цифровізація», на думку К. О. Січкаренко, є представлення об'єкту дослідження як синтетичної категорії, під якою автор розуміє всі соціально-економічні процеси, в основі яких лежить використання сучасних цифрових технологій [26, с. 31], до яких дослідник відносить використання можливостей навігації, автоматизацію виробництва, нові принципи організації ринку праці тощо.

За умов цифровізації в епоху економіки знань, наголошують С. М. Веретюк та В. В. Пілінський, домінують знання суб'єктів господарювання та нематеріальне виробництво, як базовий показник під час визначення інформаційного суспільства. Необхідно приділяти прискіпливу увагу гармонійному розвитку ключових елементів цифрової економіки, інформаційного суспільства та процесів цифровізації [27, с. 52].

Визначення цифровізації, яке надала Г. Б. Соколова, фактично дублює визначення окреслене в урядовій Концепції розвитку цифрової економіки та суспільства України, в якій наведене поняття трактується як насичення економіки та суспільства цифровими пристроями, які взаємодіють один з одним [28, с. 94]. Вважаємо наведене визначення не розкриває усієї сукупності складових елементів, які, на нашу думку, необхідно включати в поняття «цифровізація».

Цифровізаційні процеси, за переконанням Г. Т. Карчевої, передбачають використання інформаційно-комунікаційних технологій в усіх сферах соціальноекономічного життя суспільства, що дозволяє підвищувати ефективність функціонування як окремих суб'єктів господарювання, та і підвищувати якість життя населення [29, с. 14].

У національній економічній стратегії розвитку нашої держави проголошеній у 2021 році окреслено основні вектори економічного розвитку України до 2030 року, в яких зазначається, що цифровізація - це впровадження цифрових технологій в усі сфери життя: від взаємодії між людьми до промислових виробництв, від предметів побуту до дитячих іграшок, одягу тощо. Це перехід біологічних та фізичних систем у кібербіологічні та кіберфізичні (об’єднання фізичних та обчислювальних компонентів). Перехід діяльності з реального світу у світ віртуальний (онлайн) [30].

Міністр з цифрової трансформації Михайло Федоров, на відкритті другого дня Всеукраїнського форуму «Україна 30. Цифровізація» (травень 2021 року) зауважив, що цифрова трансформація нашої країни - це в першу чергу зручність для громадян. Це антикорупція. Це можливість забезпечити рівний доступ для всіх українців до ресурсів. Це також зміни, спрощення, перетворення і часто ліквідація певних галузей та напрямків. Тому важливо побудувати ефективний менеджмент на рівні всієї держави. Коли ми це виконаємо, ми отримаємо державу, як зручний сервіс [31].

3 юридичної точки розу, вирішення проблеми уніфікації підходів до визначення ключових понять із сфери цифрової економіки пропонує член-кореспондент Національної академії правових наук України О. М. Вінник, яка пропонує закріпити ключові терміни цифровізації в кодифікованому акті, яким може бути Закон України «Про цифрову економіку», що дозволить удосконалити законодавство в окресленій сфері з точки зору змісту та форми, з метою адаптації нормативно-правових актів до 
реалій та вимог сьогодення [32, с. 165]. Схожа думка щодо цифровізації процесів у сучасному судочинстві простежується в роботі В. С. Рудюк [33, с. 83].

Досліджена проблематика категоріальних особливостей застосування та специфіки трактування поняття «цифровізація» на теренах вітчизняної науки дозволяє стверджувати наступне:

- по-перше, останніми роками з'явилась значна кількість наукових праць присвячених темі роботи, що значним чином актуалізує об'єкт та напрям дослідження;

- по-друге, в українській науці немає чіткого розуміння та єдності думок щодо трактування поняття «цифровізація», значна кількість науковців або копіюють надбання закордонних вчених, або спираються на урядову Концепцію розвитку цифрової економіки та суспільства України;

- по-третє, в процесі дослідження виявлено, що переважна більшість науковців використовують економічний та соціальний підхід до визначення поняття «цифровізація»;

- по-четверте, слід також звернути увагу на те, що в працях окремих сучасних авторів наголошується на необхідності закріплення поняття «цифровізація» в кодифікованому акті;

- по-п’яте, незважаючи на значну кількість праць, проблематика цифровізації економіки потребує подальших поглиблених досліджень, оскільки вона поширюється на все більшу кількість процесів та процедур, що значно прискорює швидкість трансформаційних змін, які відбуваються в економіці та суспільстві.

Проаналізувавши наведену сукупність трактувань поняття «цифровізація» в межах вітчизняного та зарубіжного простору вважаємо за доцільне провести групування досліджуваної категорії згідно технологічного, економічного, соціального, філософського та нормативного підходів, а також виділити прибічників кожного 3 напрямів, які наведені на рис. 1.

\begin{tabular}{|c|c|c|}
\hline Технологічний: & \multirow[b]{2}{*}{$\begin{array}{c}\text { КЛАСИФІКАЦІЯ ПІДХОДІВ } \\
\text { ДО ТРАКТУВАННЯ } \\
\text { ПОНЯТТЯ } \\
\text { "ЦИФРОВІЗАЦІЯ" }\end{array}$} & Економічний: \\
\hline $\begin{array}{l}\text { Н. Негропонте, Р. Кац, } \\
\text { М. Ел-Шими, Б. ван Арк, } \\
\text { К. Елдінг, Р. Морріс } \\
\text { Г. Б. Соколова }\end{array}$ & & $\begin{array}{l}\text { М. Муро, Дж. Грей, Б. Румпе, } \\
\text { М. Шраге, Н. Колін, Б. Гейтс, } \\
\text { В. І. Ляшенко, С. В. Коляденко, } \\
\text { О. С. Вишневський, С. М. Веретюк, } \\
\text { В. В. Пілінський, Г. Т. Карчева }\end{array}$ \\
\hline Соціальний: & Філософський: & Нормативний: \\
\hline $\begin{array}{c}\text { Дж. С. Бреннен, Д. Крейс, } \\
\text { О. В. Данніков, В. С. Куйбіда, } \\
\text { Н. М. Краус }\end{array}$ & $\begin{array}{c}\text { Д. Тапскотт, } \\
\text { К. О. Січкаренко }\end{array}$ & $\begin{array}{l}\text { О. М. Вінник, } \\
\text { В. С. Рудюк }\end{array}$ \\
\hline
\end{tabular}

Рис. 1. Підходи до трактування поняття «цифровізація»

Джерело: згруповано та структуровано автором

3 метою формування єдності трактування досліджуваної категорії з точки зору запропонованих на рис. 1 підходів 3 акумулюємо сутнісне бачення категорії «цифровізація» згідно виділених технологічного, економічного, соціального, філософського та нормативного підходів, які об'єднаємо в таблиці 1. 
Таблиця 1

Сутність трактування поняття «цифровізація» згідно запропонованих підходів

\begin{tabular}{|l|l|}
\hline \multicolumn{1}{|c|}{ Підходи } & \multicolumn{1}{|c|}{ Сутність трактування } \\
\hline Технологічний & $\begin{array}{l}\text { Відбуваються соціально-економічні трансформації ініційовані масовим } \\
\text { впровадженням і використанням інформаційно-комунікаційних (цифрових) } \\
\text { технологій (створення, збір, обробка, зберігання, перетворення, обмін і } \\
\text { передача інформації). Відбуваєтья оцифровка всього, що можна } \\
\text { оцифрувати. }\end{array}$ \\
\hline Економічний & $\begin{array}{l}\text { Зміна природи та бізнес-моделі економічних відносин, їх суб’єктивно- } \\
\text { об’єктивної орієнтованості (перехід до цифрового бізнесу). Надання нових } \\
\text { можливостей отримання прибутку та створення цінності; вдосконалення } \\
\text { управління виробництвом товарів і послуг; вирішення нагальних } \\
\text { економічних проблем в розрізі окремих держав, регіонів, галузей та } \\
\text { підприємств. }\end{array}$ \\
\hline Соціальний & $\begin{array}{l}\text { Здійснюється перехід від аналогових інструментів взаємодії в суспільстві } \\
\text { до цифрових, ключовим у процесі цифровізаціїє обмін знаннями, } \\
\text { технологіями, інформацією, а також люди, які здатні приймати участь у } \\
\text { наведеному процесі та управляти ним з метою вдосконалення } \\
\text { життєдіяльності людини, суспільства і держави. }\end{array}$ \\
\hline Філософський & $\begin{array}{l}\text { Зміна загальної парадигми розвитку суспільства (думок, дій, уявлень, } \\
\text { бачень, механізмів спілкування) як із зовнішнім світом, так і один з одним. }\end{array}$ \\
\hline Нормативний & $\begin{array}{l}\text { Передбачає необхідність чіткого закріплення ключових термінів } \\
\text { цифровізації в кодифікованому акті (Законі), як відправної точки } \\
\text { раціоналізації права в сфері цифрових технологій. }\end{array}$ \\
\hline
\end{tabular}

Джерело: систематизовано автором на основі [3-32]

В процесі вивчення наукової літератури із обраної проблематики ми виявили ще один близький до цифровізації термін - цифрове перетворення, у більшості досліджених автором джерел ці терміни використовуються як взаємозамінні, хоча якщо розглядати наведені категорії з технічної точки зору, то виявимо деякі суттєві відмінності.

Термін «цифровий» зазвичай відноситься до зберігання даних або інформації в формі цифрових сигналів. У вищезазначеному сенсі цей термін використовується в основному в таких сферах як зберігання даних, або цифрова музика. По-суті описується процес, при якому інші форми репрезентації перетворюються в цифровий формат. У бізнес-контексті «аналітикою» може вважатися подальша оцифровка інформації, генерація нового розуміння, уявлення - на основі яких можна приймати більш ефективні управлінські рішення.

У глобальній науковій спільноті ведеться активна дискусія щодо визначення поняття цифровізація та окреслення елементів, складових та чинників які слід включати в вищенаведену категорію. В процесі дослідження автором не виявлено єдиного методологічного підходу до визначення наведеної категорії. Ще заплутанішим i складнішим $\epsilon$ визначення того, які технології слід відносити чи не відносити до цифрових [34, с. 63].

Проведений аналіз дозволяє стверджувати, що теоретичне обгрунтування, тлумачення та використання поняття «цифровізація» в межах вітчизняної науки та суспільства спирається здебільшого на етимологію запозичених закордонних, переважно англомовних, термінів. Переконані в необхідності уточнення семантики та сутності досліджуваної дефініції, оскільки за сучасних умов використання поняття «цифровізація» можливе лише для опису теоретичних конструкцій майбутніх змін в економіці, підприємстві та суспільстві. 
Висновки. Проаналізувавши категоріальні особливості та специфіку трактування поняття «цифровізація» можна зробити висновки, які містяться в наступних положеннях:

- «цифровізація» розглядається закордонними та вітчизняними авторами як окремий сучасний науковий напрям, а основна частина досліджень сконцентрована на впливі цифровізації на сталий розвиток економічних систем в розрізі окремих країн, регіонів, галузей, підприємств і т.д. Окремі дослідники [5;14; 17] поглиблено аналізують вплив інформаційно-комунікаційних технологій на зміни, які відбуваються в соціумі та їх вплив на майбутній розвиток суспільства;

- окремі англомовні наукові праці пов'язані із цифровою економікою акцентують увагу на впливі цифровізації на ефективність функціонування глобальної економіки взагалі та виявленні механізмів і наслідків їі впливу на сталий розвиток окремих країн, регіонів, підприємств. Переконані в тому, що процес цифровізації не є самоціллю підприємства, регіону чи держави, а виступає лише інструментом досягнення мети сталого розвитку;

- проблематика цифровізації економіки та ії теоретичного підгрунтя знаходиться у полі зору вітчизняної наукової спільноти, особливий поштовх спостерігається із започаткуванням активної роботи Міністерства цифрової трансформації;

- визначення «цифровізація» вітчизняних науковців здебільшого копіюють або базуються на трактуванні понять їх західних колег, в яких основні акценти цифровізаційних процесів робляться на впливі інформаційно-комунікаційних технологій на функціонування існуючих економічних систем через призму підвищення ефективності діяльності господарюючих суб'єктів;

- проведено групування досліджуваної категорії та визначень науковців згідно технологічного, економічного, соціального, філософського та нормативного підходів 3 окресленням сутності трактування кожної групи, що дозволило систематизувати вектори визначення категорії «цифровізація» в умовах сучасного динамічного розвитку економіки та суспільства.

\section{Список бібліографічного опису:}

1. Riepina I.M., Lavrenenko V.V., Petrenko L.A., Shvydanenko G.O., etc. Innovative entrepreneurship: approach to facing relevant socio-humanitarian and technological challenges: collective monograph. Lviv-Toruń: Liha-Pres, 2019. 204 p.

2. Руденко М.В., Криворучко В.О. Інфляція знань у концепції сучасного підприємства. Інвестицї̈ досвід та практика. 2017. № 17. C. 39-43.

3. Brennen, J. S., Kreiss, D. Digitalization. In The International Encyclopedia of Communication Theory and Philosophy. URL: https://onlinelibrary.wiley.com/action/ showCitFormats?doi=10.1002\%2F9781118766804.wbiect111.

4. Negroponte N. Being Digital. New York: Knopf, 1995. 256 p.

5. Tapscott D. The Digital Economy. Promise and Peril in the Age of Networked Intelligence. New York: McGraw-Hill, 1995. $345 \mathrm{p}$.

6. Ляшенко В.І., Вишневський О.С. Цифрова модернізація економіки України як можливість проривного розвитку: монографія. К.: НАН України, 2018. 252 с.

7. Данніков О.В., Січкаренко К.О. Концептуальні засади цифровізації економіки України. Інфраструктура ринку. 2018. № 17. С. 73-79.

8. Коляденко С.В. Цифрова економіка: передумови та етапи становлення в Україні і у світі. Економіка. Фінанси. Менеджмент: актуальні питання науки і практики. 2016. № 6. С. 105-112.

9. Краус Н.М., Голобородько О.П., Краус К.М. Цифрова економіка: тренди та перспективи авангардного характеру розвитку. Ефективна економіка. 2018. №1. URL: http://www.economy.nayka.com.ua/pdf/1_2018/8.pdf.

10. Пантєлєєва Н.М., Колодій С.Ю., Ребрик М.А. Цифрова економіка як ключовий тренд розвитку постіндустріального суспільства: монографія. К.: ДВНЗ «Університет банківської справи», 2019. 299 с.

11. Bell D. The coming of post-industrial society: a venture in social forecasting. N.Y.: Basic Books, 1976. 528 p.

12. Porat M. The Information Economy: Definition and Measurement. Washington: U.S. Government Printing Office, 1977. $319 \mathrm{p}$.

13. Toffler A. Power Shift. Knowledge, Wealth and Violence at the Edge of the 21st Century. N.Y., 1990. 601 p.

14. Katz R. The transformative economic impact of digital technology. URL: https://unctad.org/meetings/en/Presentation/ ecn162015p09_Katz_en.pdf

15. Gupta M. What is Digitization, Digitalization, and Digital Transformation? URL: https://www.arcweb.com/blog/whatdigitization-digitalization-digital-transformation

16. Muro M. Digitalization and the American workforce. URL: https://www.brookings.edu/research/digitalization-and-theamerican-workforce. 
17. Gray J., Rumpe B. Models for digitalization. Journal of Software \& System Modelling. 2015. №14 (1). P. 1319-1320.

18. Bloomberg J. Digitization, Digitalization, And Digital Transformation: Confuse Them At Your Peril. URL: https://www.forbes.com/sites/ jasonbloomberg/2018/04/29/digitization-digitalization-and-digital-transformation-confusethem-at-your-peril/\#1e1fe3d02f2c.

19. Khosrow-Pour M. Encyclopedia of Information Science and Technology, Fourth Edition (10 Volumes). IGI Global, June, 2017. 8104p.

20. van Ark B. The productivity paradox of the new digital economy. International Productivity Monitor. 2016. № 3. P. 3-18. 21. Elding C., Morris R. Digitalisation and its impact on the economy: insights from a survey of large companies. URL: https://www.ecb.europa.eu/pub/economic-bulletin/focus/2018/html/ecb.ebbox201807_04.en.html

22. Gates B. Business at the Speed of Thought. URL: https://english-e-reader.net/book/business-at-the-speed-of-thought-billgates

23. Про схвалення Концепції розвитку цифрової економіки та суспільства України на 2018-2020 роки та затвердження плану заходів щодо iï реалізації : Розпорядження КМУ від 17 січня 2018 p. № 67-p. URL: http://zakon.rada.gov.ua/laws/show/67-2018-\%D1\%80.

24. Clark C. The conditions of economic progress. N.Y.: St. Martin's Press, 1957. 720 p.

25. Куйбіда В.С., Карпенко О.В., Наместнік В.В. Цифрове врядування в Україні: базові дефініції понятійнокатегоріального апарату. Вісник Національної академії держсавного управління при президентові України. Серія “Державне управління”. 2018. № 1. С. 5-11.

26. Січкаренко К.О. Цифровізація як фактор змін у міжнародних економічних відносинах. Приазовський економічний вісник. 2018. № 3(08). С. 30-34.

27. Веретюк С.М., Пілінський В.В. Визначення пріоритетних напрямків розвитку цифрової економіки в Україні. Наукові записки Украӥнського науково-дослідного інституту зв 'язку. 2016. № 2(42). С. 51-58.

28. Соколова Г.Б. Деякі аспекти розвитку ичиррової економіки в Украӥні. Економічний вісник Донбасу. 2018. № 1(51). C. $92-96$.

29. Карчева Г.Т., Огородня Д.В., В.А. Опенька В.А. Цифрова економіка та їі вплив на розвиток національної та міжнародної економіки. Фінансовий простір. 2017. № 3(27). С. 13-21.

30. Вектори економічного розвитку 2030. URL: https://nes2030.org.ua/docs/doc-vector.pdf

31. Федоров М. Цифровізація - це поступове перетворення усіх державних послуг на зручні онлайн-сервіси. URL: https://www.kmu.gov.ua/news/mihajlo-fedorov-cifrovizaciya-ce-postupove-peretvorennya-usih-derzhavnih-poslug-nazruchni-onlajn-servisi.

32. Вінник О.М. Регулювання відносин у сфері цифрової економіки: проблеми термінології. Підприємництво, господарство і право. 2017. № 11. С. 163-166.

33. Рудюк В.С. Диджиталізація в сучасному судочинстві. Філософські та методологічні проблеми права. 2020. № 2 (20) C. $82-85$.

34. Руденко М.В. Цифровізація економіки: нові можливості та перспективи. Економіка та держава. 2018. № 11. С. $61-65$.

\section{References:}

1. Riepina, I.M., Lavrenenko, V.V., Petrenko, L.A., Shvydanenko, G.O., etc. (2019). Innovative entrepreneurship: approach to facing relevant socio-humanitarian and technological challenges: collective monograph. Lviv-Toruń: Liha-Pres, 204 p. [in English].

2. Rudenko M.V., Kryvoruchko V.O. (2017). Inflyatsiya znan' u kontseptsiyi suchasnoho pidpryyemstva [Inflation of knowledge in the concept of modern enterprise]. Investment experience and practice. №17, P. 39-43. [in Ukrainian].

3. Brennen, J. S., Kreiss, D. (2016). Digitalization. In The International Encyclopedia of Communication Theory and Philosophy. $\quad$ Recived

https://onlinelibrary.wiley.com/action/showCitFormats?doi=10.1002\%2F9781118766804.wbiect111. [in Ukrainian].

4. Negroponte N. (1995). Being Digital. New York: Knopf, 256 p. [in English].

5. Tapscott D. (1995). The Digital Economy. Promise and Peril in the Age of Networked Intelligence. New York: McGrawHill, 345 p. [in English].

6. Lyashenko V.I., Vyshnevs'kyy O.S. (2018). Tsyfrova modernizatsiya ekonomiky Ukrayiny yak mozhlyvist' proryvnoho rozvytku: monohrafiya [Digital modernization of Ukraine's economy as an opportunity for breakthrough development: a monograph]. K.: NAS of Ukraine, 252 p. [in Ukrainian].

7. Dannikov O.V., Sichkarenko K.O. (2018). Kontseptual'ni zasady tsyfrovizatsiyi ekonomiky Ukrayiny [Conceptual principles of digitalization of Ukraine's economy]. Market infrastructure. № 17. P. 73-79. [in Ukrainian].

8. Kolyadenko S.V. (2016). Tsyfrova ekonomika: peredumovy ta etapy stanovlennya v Ukrayini i u sviti [Digital economy: preconditions and stages of formation in Ukraine and in the world]. Economy. Finances. Management: current issues of science and practice. № 6. P. 105-112. [in Ukrainian].

9. Kraus N.M., Holoborod'ko O.P., Kraus K.M. (2018). Tsyfrova ekonomika: trendy ta perspektyvy avanhardnoho kharakteru rozvytku [Digital economy: trends and prospects of avant-garde development]. Efficient economy. №1. Recived from: http://www.economy.nayka.com.ua/pdf/1_2018/8.pdf. [in Ukrainian].

10. Pantyelyeyeva N.M., Kolodiy S.Yu., Rebryk M.A. (2019). Tsyfrova ekonomika yak klyuchovyy trend rozvytku postindustrial'noho suspil'stva: monohrafiya. [Digital economy as a key trend in the development of post-industrial society: a monograph]. K.: Banking University, 299 p. [in Ukrainian].

11. Bell D. (1976). The coming of post-industrial society: a venture in social forecasting. N.Y.: Basic Books, 528 p. [in English].

12. Porat M. (1977). The Information Economy: Definition and Measurement. Washington: U.S. Government Printing Office, 319 p. [in English].

13. Toffler A. (1990). Power Shift. Knowledge, Wealth and Violence at the Edge of the 21st Century. N.Y., 601 p. [in English]. 
14. Katz R. (2015). The transformative economic impact of digital technology. Recived from: https://unctad.org/meetings/en/Presentation/ ecn162015p09_Katz_en.pdf [in English].

15. Gupta M. What is Digitization, Digitalization, and Digital Transformation? Recived from: https://www.arcweb.com/blog/what-digitization-digitalization-digital-transformation [in English].

16. Muro M. Digitalization and the American workforce. Recived from: https://www.brookings.edu/research/digitalizationand-the-american-workforce. [in English].

17. Gray J., Rumpe B. (2015). Models for digitalization. Journal of Software \& System Modelling. №14 (1), P. 1319-1320. [in English].

18. Bloomberg J. Digitization, Digitalization, And Digital Transformation: Confuse Them At Your Peril. Recived from: https://www.forbes.com/sites/ jasonbloomberg/2018/04/29/digitization-digitalization-and-digital-transformation-confusethem-at-your-peril/\#1e1fe3d02f2c. [in English].

19. Khosrow-Pour M. (2017). Encyclopedia of Information Science and Technology, Fourth Edition (10 Volumes). IGI Global, 8104p. [in English].

20. van Ark B. (2016). The productivity paradox of the new digital economy. International Productivity Monitor. № 3, P. $3-$ 18. [in English].

21. Elding C., Morris R. Digitalisation and its impact on the economy: insights from a survey of large companies. Recived from: https://www.ecb.europa.eu/pub/economic-bulletin/focus/2018/html/ecb.ebbox201807_04.en.html [in English].

22. Gates B. Business at the Speed of Thought. Recived from: https://english-e-reader.net/book/business-at-the-speed-ofthought-bill-gates [in English].

23. Pro skhvalennya Kontseptsiyi rozvytku tsyfrovoyi ekonomiky ta suspil'stva Ukrayiny na 2018-2020 roky ta zatverdzhennya planu zakhodiv shchodo yiyi realizatsiyi [On approval of the Concept of development of the digital economy and society of Ukraine for 2018-2020 and approval of the action plan for its implementation]. Order of the Cabinet of Ministers of January 17, 2018 № 67-r. Recived from: http://zakon.rada.gov.ua/laws/show/67-2018-\%D1\%80 [in Ukrainian].

24. Clark C. (1957). The conditions of economic progress. N.Y.: St. Martin's Press, 720 p. [in English].

25. Kuybida V.S., Karpenko O.V., Namestnik V.V. (2018). Tsyfrove vryaduvannya v Ukrayini: bazovi definitsiyi ponyatiynokatehorial'noho aparatu [Digital governance in Ukraine: basic definitions of the conceptual and categorical apparatus]. Bulletin of the National Academy of Public Administration under the President of Ukraine. Public Administration Series. № 1. P. 5-11. [in Ukrainian].

26. Sichkarenko K.O. (2018). Tsyfrovizatsiya yak faktor zmin u mizhnarodnykh ekonomichnykh vidnosynakh [Digitization as a factor of change in international economic relations]. Priazovsky Economic Bulletin. № 3 (08). P. 30-34. [in Ukrainian].

27. Veretyuk S.M., Pilins'kyy V.V. (2016). Vyznachennya priorytetnykh napryamkiv rozvytku tsyfrovoyi ekonomiky v Ukrayini [Identification of priority areas of digital economy development in Ukraine]. Scientific notes of the Ukrainian Research Institute of Communications. № 2 (42), P. 51-58. [in Ukrainian].

28. Sokolova G.B. (2018). Deyaki aspekty rozvytku tsyfrovoyi ekonomiky v Ukrayini [Some aspects of digital economy development in Ukraine]. Economic Bulletin of Donbass. № 1(51). P. 92-96. [in Ukrainian].

29. Karcheva H.T., Ohorodnya D.V., V.A. Open'ka V.A. (2017). Tsyfrova ekonomika ta yiyi vplyv na rozvytok natsional'noyi ta mizhnarodnoyi ekonomiky [Digital economy and its impact on the development of national and international economy]. Financial space. № 3 (27). P. 13-21. [in Ukrainian].

30. Vektory ekonomichnoho rozvytku 2030 [Vectors of economic development 2030]. Recived from: https://nes2030.org.ua/docs/doc-vector.pdf [in Ukrainian].

31. Fedorov M. Tsyfrovizatsiya - tse postupove peretvorennya usikh derzhavnykh posluh na zruchni onlayn-servisy [Digitalization is a gradual transformation of all public services into convenient on-line services]. Recived from: https://www.kmu.gov.ua/news/mihajlo-fedorov-cifrovizaciya-ce-postupove-peretvorennya-usih-derzhavnih-poslug-nazruchni-onlajn-servisi [in Ukrainian].

32. Vinnyk O.M. (2017). Rehulyuvannya vidnosyn u sferi tsyfrovoyi ekonomiky: problemy terminolohiyi [Regulation of relations in the digital economy: problems of terminology]. Entrepreneurship, economy and law. № 11. P. 163-166. [in Ukrainian].

33. Rudyuk V.S. (2020). Dydzhytalizatsiya v suchasnomu sudochynstvi [Digitalization in modern justice]. Philosophical and methodological problems of law. № 2 (20) P. 82-85. [in Ukrainian].

34. Rudenko M.V. (2018). Tsyfrovizatsiya ekonomiky: novi mozhlyvosti ta perspektyvy [Digitization of the economy: new opportunities and prospects]. Economy and state. № 11. P. 61-65. [in Ukrainian].

\section{Дата подання публікації 15.10.2021p.}

